\title{
LIETUVOS URBANISTINIŲ SISTEMŲ TRANSFORMACIJOS IR MUTACIJOS
}

\author{
Pranciškus Juškevičiuss ${ }^{1}$, Skirmantė Mozūriūnaitė ${ }^{2}$, Saulius Motieka ${ }^{3}$ \\ ${ }^{1,2}$ Urbanistikos katedra, Vilniaus Gedimino technikos universitetas, \\ Pylimo g. 26/Trakug. 1, LT-01332 Vilnius, Lietuva \\ ${ }^{3} S t$, ,Vilniaus planas", Konstitucijos pr. 3, LT-09601 Vilnius; \\ Urbanistikos katedra, Vilniaus Gedimino technikos universitetas, \\ Pylimo g. 26/Trakug. 1, LT-01332 Vilnius, Lietuva \\ El.paštas: ${ }^{1}$ pjuskevicius@gmail.com, ${ }^{2}$ smozuriunaite@gmail.com, ${ }^{3}$ saulius.motieka@vplanas.lt
}

Iteikta 20091021

\begin{abstract}
Santrauka. Straipsnyje aptariamas Lietuvos naujos urbanistinès praktikos ir teorijos kūrimosi procesas, kuris daugeliu atvejų yra nesèkmingas. Per $20 \mathrm{~m}$. susiformavo 3 probleminès sritys: savaiminiai spontaniški procesai - miesto rūdijimas arba mutacijos - nèra oficialiai pripažinti; suplanuotos miestų struktūrų transformacijos - jos neturi įvertinimo ir ịgyvendinimo priemonių; mokslinès ir profesinès veiklos devalvavimas. Nagrinëjamos urbanistinio planavimo ir jo igyvendinimo per tam tikrą laiką ir tam tikroje erdvèje disproporcijos, darniosios plètros principų ir realiai vykstančių urbanistinių mutacijų turinio vektorių esminis išsiskyrimas. Siūlomi esminiai pakeitimai: pripažinti realiai egzistuojančius procesus ir urbanistinių sistemų ịvairovę bei procesų tikimybinị pobūdį; periodinị planavimą transformuoti $\mathfrak{i}$ tęstinị lankstų procesą; planavimo sprendinių privalomumą - ị rekomendacijas; pripažinti visuomenės dalyvavimo privačių ir viešų interesų atskyrimo pagrindimą planavimo procese, pripažinti transformacijų ir mutacijų visumos ryšius.
\end{abstract}

Reikšminiai žodžiai: mutacijos, darnioji plètra, transformacijos, miestų ekspansija, plètros valdymas, urbanistinis planavimas.

\section{Ivadas}

Miestai niekada nenustojo vystęsi ir kol kas nèra jokiu prognozuojamų veiksnių, kurie galetų sustabdyti jų kiekybinį bei kokybinį vystymąsi. Nuolat kinta miestų sistemos, jų struktūros ir formos, turinys, reikšmès. Šie procesai pastarąji dešimtmetị labai sustiprèjo ypač metropoliuose ir didmiesčiuose. Jų veiklos aktyvumas, sisteminès reikšmès didejjimas yra svarbiausias šiuolaikinės urbanizacijos požymis. Pagrindiniai veiksniai yra susiję su technologijų, globalizacijos ir gyvenimo būdo kaita, kuri kartu su lokaliais veiksniais sukūrè nepaprastai didelę sąlygų miestų vystymuisi ịvairovę. Šiandien stambioms sistemoms apibūdinti vartojama daugybė sąvoku - globalus miestas; politinis miestas; de facto miestas; miestas archipelagas; hipermiestas; megapolis; metropolis; miestas valstybe; miestas, netu- rintis laike ir erdveje baigtinių ribų; mobilus miestas; „išplaukęs“ miestas, kurio didžiausią dalị sudaro trečiosios erdvès (t. y. neišvystytos pagal trečiojo pasaulio šalių analogiją); miestas „be urbanisto“, t. y. neplanuojamas ir nevaldomas (Equipe... 2009; Gosse 2004; Les mutations... 2007; Koolhaas et al. 2000; Nielsen et al. 2004) - neišreiškia realios ịvairovès. Kaip kontrastas mažesnių miestų, nutolusių nuo pagrindinių miestų centrų itakos, vystymasis yra kitoks - regresinio ir priklausomybès nuo didžiųjų miestų pobūdžio.

Politinių, ekonominių ir socialinių santykių esminè kaita ir jų vystymasis rinkos sąlygomis, restitucija, ryškaus pakilimo bei gilaus nuosmukio laikotarpiai kartu su e. technologijomis, gyvenimo būdo pokyčiais, intensyvia gyventojų emigracija ir jos pasekmèmis, taip 
pat šalies urbanistinès sistemos vystymosi komunikacinè ir kitokia atskirtis - tai aplinka, kurioje kūrèsi nauji Lietuvos urbanistinès praktikos bei teorijos pradmenys. Kūrimosi procesas nepaprastai prieštaringas ir daugeliu atvejų nesėkmingas. Tokị faktą sèkmingai konstatavo du įvykę urbanistikos forumai, o antrame suformuluoti konkuruojantys teritoriju planavimo ir urbanistinès plètros pasiūlymai (Darnioji plètra... 2008). Kaip ir anksčiau nesèkmingai tikèta, kad jie bus priimti ir panaudoti kaip profesionalūs naudingi pasiūlymai. Tai vienas iš paradoksų, kai nedidelių aktyvistų grupelių nuomonè yra veiksminga, o profesinès visuomenès - atvirkščiai.

Lietuvos urbanistikos srityje per beveik $20 \mathrm{~m}$. susiformavo trys probleminès sritys. Pirmajai Lietuvoje, kaip ir posocialistinėse bei senosiose ES šalyse, būdingi tie patys suburbanizacijos, ruralurbanizacijos, metropolizacijos, socialinès poliarizacijos bei atskirties, miestų struktūrų skeldèjimo ir išskydimo, miestų centrų regresijos bei kiti procesai (Spatial planning... 2006), nors Lietuvoje jie palyginti nèra tokie ryškūs dèl mažo socialinio, demografinio, ekonominio potencialo. Tai spontaniški ir teritorijų planavimo dokumentuose (svarbiausia - bendruosiuose planuose) nenumatyti procesai, kuriuose aktyviai dalyvauja bei juos inicijuoja gyventojai, verslo atstovai, skatinami susiklosčiusių sąlygų ir aplinkybių bei tikslų. Problemos esmé urbanistinèje terpéje yra ta, kad Lietuvoje tokie savaiminiai procesai ir jų pasekmès (juos siūlome vadinti mutacijomis $^{\star}$ ) urbanistinèse struktūrose, funkcineje ir socialineje raidoje bei kitose urbanistikos srityse oficialiai nèra pripažinti. Mutacijomis vadinami prievartiniai pokyčiai, kurie vyksta, kai elementai yra veikiami prievartiniu būdu planuojant miestus, keičiant jų funkcinę struktūrą ir zonuojant. Mutacijų laisvoji kaita - tai ekonominių, socialinių, techninių, gamtos reiškinių pokyčiai, netiesiogiai lemiantys miesto elementus ir ryšius (Kalltorp et al. 1997). Todèl aišku, kad šioje situacijoje nèra ir nekaupiama atitinkama informacija objektyviai identifikuoti pačius urbanistinius procesus, vertinti jų neigiamas bei teigiamas pasekmes, formuoti atitinkamas reguliavimo strategijas ir konkrečius mechanizmus.

\footnotetext{
"mutacija - tai kaita, kitimas ir dinamiška transformacija, kurios pasekmè yra nuoseklus arba staigus evoliucijos procesas, sukeltas veiksnių (Ivanow 2003). İvairioje urbanistinès tematikos literatūroje sąvokos mutacija ir transformacija Prancūzijoje, Jungtinëje Karalystėje yra vartojamos laisvai. Tai, kas turi spontaniškumo, neprognozuojamumo savybes, priskiriama urbanistinių mutacijų kategorijai (pvz., Guadeloupe 2007).
}

Antroji probleminè sritis yra organizuota plètra, kurios pagrindą sudaro planavimo ir planavimo sprendinių igyvendinimo sistemos. Jų rezultatus siūlome vadinti suplanuotomis miestų struktūrų transformacijomis*. Problemos esmè ta, kad planavimo sprendinių, ypač esminių, igyvendinimas dèl finansinių, institucijų mąstymo ir elgsenos ypatybių, vadybinių gebejimų, ilgų procedūrinių grandinių bręsta ilgai, tiksliau - neapibrežtai ilgai. Greitai ir tiksliai ṫgyvendintų transformacijų lyginamasis svoris yra mažas. Problema iškyla tuomet, kai dèl aktyvaus gyvenimo tempo laiko itin sumažèja, lyginant su ankstyvesniu laiku (Bunschoten 1999). Paprastai per 5-10 m. susiformuoja neigyvendintų sprendinių kritinè masè, kuri tam tikra progresija didina ne tik problemų mastą, bet ir greitina mutacijas. Tad galima teigti, kad problemų sprendimas bei planavimo scenarijų kūrimas $5-10 \mathrm{~m}$. periodui yra planavimas būtuoju laiku - lyg praeičiai.

Trečioji problema - mokslinès ir profesinès veiklos devalvavimas. Oficialiai nepripažintas urbanistikos mokslas bei urbanistikos akademinès studijos apskritai ir tai, kad urbanistika yra tarpdisciplininè sritis, kurioje turètų būti integruojamos architektūros, civilinès inžinerijos, demografijos, geografijos, politologijos, sociologijos, teisess, ekonominkos ir kitokios žinios. Reali situacija yra priešinga: dabar yra atviras kelias subjektyvumui ir nekompetencijai bet kuriose urbanistikos bei su ja susijusiose srityse. Šios problemos įvairius aspektus plačiai nagrinėjo Z. J. Daunora $2008 \mathrm{~m}$.

Straipsnio tikslas yra iškelti urbanistinio (ir teritorijų) planavimo ir savaiminès raidos, t. y. transformacijų bei mutacijų santykių problemą, kurios sprendimas tiesiogiai susijęs su trijomis urbanistikos probleminemis sritimis, nuo kurių pažinimo priklauso ne tik siaurai suprantama urbanistinių sprendinių kokybė, bet svarbiausia - ir urbanistikos indèlis į šalies pažangą bei gyvenimo kokybę. Tai visiškai nenagrinèti dalykai. Jų egzistavimo pripažinimas ir atitinkamas ịvertinimas (jeigu toks aktas ịvyktų) būtų pirmas požymis, kad oficiali teritorijų ir kartu urbanistinio planavimo sistema gali būti atvira kokybiškam ir sisteminiam vystymui bei profesinès visuomenès dalyvavimui. Be to, tai būtų esminè paskata pradèti formuoti sistemiškai pagrịstą urbanistinio planavimo metodiką.

Pagrindinè informacinè bazè - autorių asmeninių darbų archyvai, anketinių apklausų ir kitokių tyrimų medžiaga, sukaupta rengiant Vilniaus, Klaipèdos, Palangos, Druskininkų, Ukmergès ir kitų miestų 
bendruosius planus, magistrantūros studijų ir darbo Jungtinejje Karalystëje metu.

\section{Planavimas ir igyvendinimas}

Urbanistinio planavimo prasmę ir naudą pripažista daugelis šalių, Lietuva taip pat. Tačiau vien planavimo faktas ne visada yra reikšmingas. Nuo 2002 m. galiojančio Lietuvos Respublikos teritorijos bendrojo plano (BP) reikšmè daugiau formali negu reali, nes jo sprendiniai rengti ekonominio nestabilumo (1995-1999 m., o patvirtintas tik $2002 \mathrm{~m}$.) sąlygomis ir greičiau atspindi to meto esamą būklę, bet neskatina progreso ir konkurencijos, nes pagal TPD hierarchiją privalu besąlygiškai laikytis jo sprendinių rengiant kito lygmens teritorijų planavimo dokumentus (toliau - TPD). Todèl apskričių bendrieji planai iš esmès kartoja šalies BP, tik stambesniu masteliu. O tikrieji teritorijų vystymosi veiksniai - inercija ir miestų konkurencija šalies rinkoje. Daugumos savivaldybių ir rajonų teritorijų BP, rengti 2004-2008 m., yra hipertrofuoti. Tai atitinka politikų, verslininkų ir gyventojų itin optimistines nuotaikas tuometinio ekonomikos ir nekilnojamo turto srities didžiausio klestèjimo laikotarpiu. Todèl antrajam ir trečiajam sektoriui vystyti savivaldybių politikų sprendimu rezervuota net 5 ir daugiau kartų žemès, negu galima logiškai ir dalykiškai pagrịsti toki poreiki.

Miestų bendrasis planavimas turi problemų, kurias yra užprogramavusi pati planavimo sistema. Svarbiausia, kad bendrojo plano (BP) sprendinių vi- sumos igyvendinimas suvokiamas kaip tolygus miestu vystymasis planuojamu laiko periodu (1 pav.).

Toks jų igyvendinimas rinkos sąlygomis yra neįmanomas. Tai lemia daugybè veiksnių: dalis sprendinių pasensta greičiau negu, pavyzdžiui, patvirtinamas BP; kitų igyvendinimą riboja finansavimo galimybès; keičiasi poreikiai, plètros potencialas; atsiranda naujų neprognozuotų poreikių, procesų (intensyvi gyventojų emigracija, ekonomikos nuosmukis). Taigi teoriškai simbolinę bendrojo planavimo informacinès bazès struktūrą turètume ịsivaizduoti tokią:

p - žinomi esami ir statistiškai su priimtina tikimybe prognozuojami poreikiai,

px - žinomi tik esami poreikiai, ateities poreikių tendencijos neprognozuojamos,

py - įsivaizduojami nauji poreikiai, tačiau nežinomos erdvès ir laiko tikimybès,

$\mathrm{pz}$ - nežinoma naujų poreikių atsiradimo tikimybè.

Savaime suprantama, kad kitą bazès dali turètų sudaryti galimybès g, gx, gy, gz su analogiškais požymiais. Realaus planavimo bazè yra nepalyginamai silpnesnè. Todèl sprendinių igyvendinimas iggauna atsitiktinumo ir neapibrèžtumo pobūdị. Visa tai susipina su regioninių, globalių finansinių ir ekonominių krizių ypatybėmis, kurios paprastai lemia ciklišką miestų vystymąsi (1 pav.).

Tokị reiškinị stiprina vadinamieji savaime susidarantys vystymosi ,slenksčiai“, kuriuos įveikti reikia neproporcingai daugiau resursų, negu reikètų pagal gyventojų prieaugio ar gyvenimo sąlygų gerinimo dy-

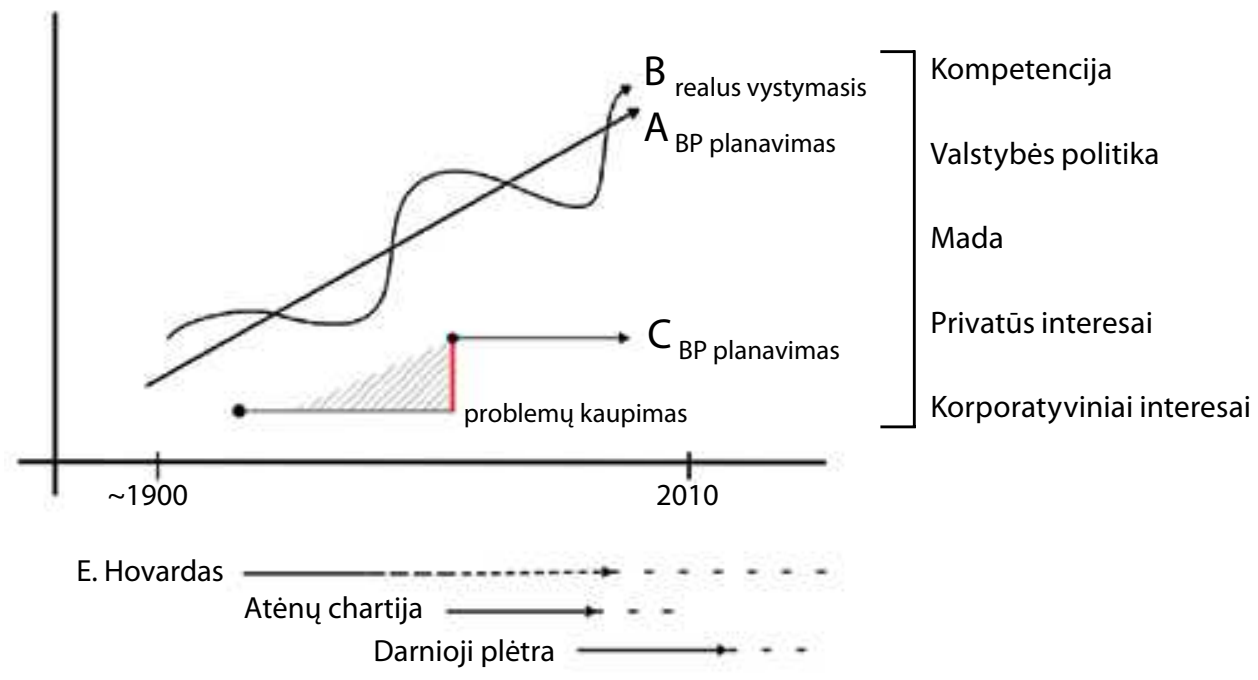

1 pav. Tiesè ir sinusoidè

Fig. 1. Straight and sinusoid 
džius. Peržengus slenksti, miesto vystymasis tampa sklandus ir efektyvus iki kito „slenksčio“ (nesenstanti B. Malisz slenksčių teorija studijoje (Kolipinski 1970) bei urbanistinio vystymosi perpetum mobile ir reguliavimo „sklendès“ straipsnyje (Berezowska-Azzag 2000)).

Nuo $2004 \mathrm{~m}$. Lietuvoje galiojantys bendrojo planavimo sistemos principai nekoreliuoja su vystymosi cikliškumu. Tai pirmoji yda - sistema de facto numato tolygų vystymąsi nuo pradinio iki planuojamojo išsivystymo lygmens (1 pav.). Tai sovietinių metų determinuoto miestų planavimo ir igyvendinimo sistemos reliktas. Tačiau niekas negali patvirtinti, kokia yra apskritai tikroji sprendinių igyvendinimo per tam tikrą laiką bei tam tikroje erdveje tikimybė. Pavyzdžiui, nuo $2002 \mathrm{~m}$. veikiančio šalies BP sprendinių igyvendinimo statistika neskelbiama. Klausimas - kodèl dabartiniame kontekste visi jo sprendiniai vertintini pagal pradinę jų prasmę ir reikšmę. Antroji yda - per sprendinių igyvendinimo laikotarpi nèra adekvačios reakcijos $\mathfrak{i}$ atsirandančias problemas ir mutacijas. Geriausiu atveju jos kaupiamos kitam po $10 \mathrm{~m}$. generaliniam perplanavimui arba tiesiog paliekamos neidentifikuotos ir nefiksuotos (2 pav.). Taigi planavimo sistema pati formuoja papildomus slenksčius.

Vien miesto BP patvirtinimo faktas sukelia įvairialypę reakciją, o tuo labiau miesto vystymo stagnacija ar regresija - gyventojų emigraciją, darbo vietų iškèlimą, patrauklumo investicijoms sumažèjimą ir pan. Maršalas Maklahanas 1967 m. teigè, kad miestai jau nebeegzistuoja, tai tik „kultūrinès šmèklos turistams“ (Mitchell 2002). Toks miestas, kaip jị suprato garsūs urbanistikos teoretikai, tokie kaip L. Mamfordas, Ch. Alenksanderis ir J. Jacobas - nebegali funkcionuoti kaip ankstesniais laikais ir sudaryti darnią visumą. Sparčiai besivystančios technologijos, ekonomika, nusistovèję teoriniai urbanistiniai modeliai ir jų integravimas planuojant yra aktuali šių dienų problema. Užsienio praktikoje taikomas tęstinio planavimo metodas suteikia daugiau lankstumo ir galimybių reaguoti ị greitai besikeičiančią politinę, ekonominę ir socialinę situaciją, nustatyti ir ịvertinti mutacijas, išvengti klaidų.

Galima konstatuoti, kad miesto vystymasis priklauso ne tiek nuo bendrojo planavimo formalios kokybès, kuriai lemiamą reikšmę turi politinis savivaldybès sprendimas, bet nuo to, ar bendrojo plano sprendiniais
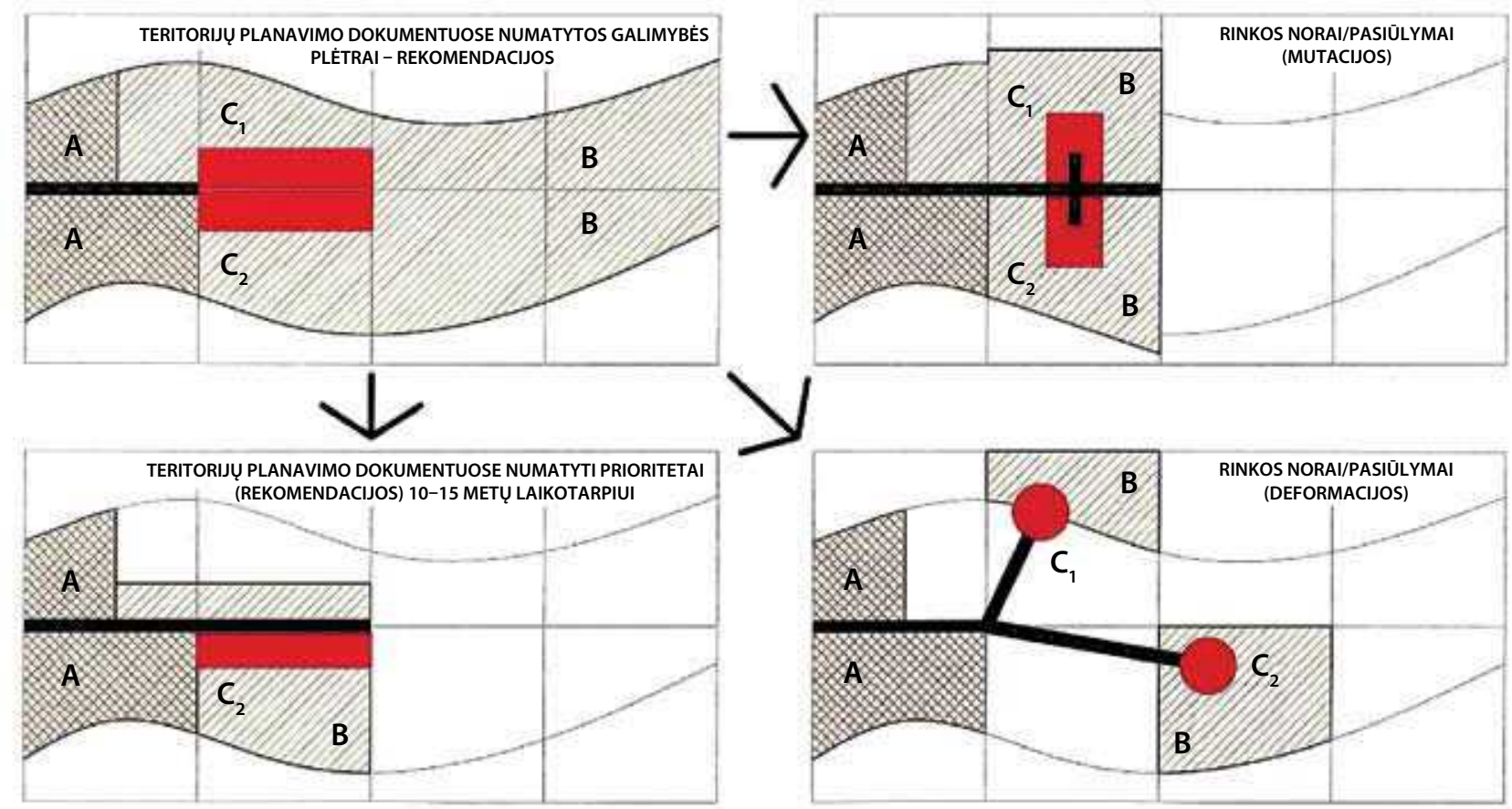

2 pav. Urbanizacijos ir planavimo procesu interpretacijos: A - esamos urbanizuotos teritorijos; B - urbanistinės plètros teritorijos; C1, C2 - lokaliniai centrai

Fig. 2. Interpretation of urbanization and planning processes: A - present urbanised territories; $\mathrm{B}$ - urban development territories; C1, C2 - local centres 
yra numatytos vystymo strategijos, siejamos su galimu teigiamų ar neigiamų mutacijų atsiradimu ir atitinkamu jų ivvertinimu, resursais ir t. t. Todèl periodiški maždaug kas $10 \mathrm{~m}$. (tai numato dabartine planavimo sistema) ar kitokị laikotarpi 2-3 m. trunkantys ,,generaliniai" planavimai yra primityvus urbanistinių procesų supratimas, kuriam tiktų problemų kaupimo ir vèluojančios reakcijos etiketė. Keli pavyzdžiai: minèti „generaliniai“ planai Vilniuje buvo patvirtinti 1980, 1998 ir 2007 m., Ukmergès miesto - 1992 m. ir galbūt $2011 \mathrm{~m}$. bus patvirtintas $2009 \mathrm{~m}$. pradètas BP. Visais šiais periodais liko daugybè neigyvendintų sprendinių, tačiau ne mažiau atsirado neplanuotų bendruosiuose planuose objektų, îvyko daugybė funkcinès struktūros pokyčiu ir t. t. Tokia situacija buvo esminis motyvas, dèl kurio iki maždaug $2005 \mathrm{~m}$. buvo silpnas suinteresuotumas bendraisiais planais. Tai buvo savotiškos laisvès nuo procedūrų ir įvairių vertinimų bei greitos reakcijos laikotarpis, tačiau juo viešpatavo sistemiškai neefektyvus vadinamasis ,sklypinis“ planavimas.

Pagal dabartines taisykles nereikia keisti BP, jeigu keitimų plotas užima ne didesnę kaip $20 \%$ gyvenamosios ir kitos paskirties teritorijos dali. Tai kitose šalyse iprasto tęstinio planavimo nevykusi imitacija (tiesa, iki $2004 \mathrm{~m}$. pirmajame Lietuvos teritoriju planavimo istatyme buvo tęstinio planavimo nuostata - operatyvusis planavimas). Daugeliu požiūriu tai rizikinga nuostata (manipuliaciju ir protekcionizmo prielaidos, viešumo stoka), niekais verčianti objektyvesnio planavimo principus.

Bendrojo planavimo sistemos efektyvumas yra sietinas su kitokiais esminiais principais.

Pirma, bendrasis planavimas negali kas 10 ar kas $15 \mathrm{~m}$. prasidèti nuo nulio, o sprendiniai galioti tik ribotą laikotarpị. Jie turètų galioti tol, kol bus iggyvendinti arba kol juos pakeis kiti geresni sprendiniai ir nebūtinai urbanistiniai (efektyvesni gali būti organizaciniai, finansiniai, juridiniai ir t. t.).

Antra, praktiškai tai reiškia, kad BP sprendiniai yra rekomendacijos, kurios gali būti łgyvendintos tik esant galimybems ir su sąlyga, kad jų aktualumas yra laiko ir kitaip patvirtintas pagal igyvendinimo prioritetiškumą (2 pav.).

Trečia, rinka reaguoja ị pokyčius daug greičiau negu bet kuri administracinè struktūra, tvarkanti planavimo sistemą ir bendruosius planus. Reakcija pagerètų, jeigu būtų leidžiama miesto vystymo pasiūlymus teikti visiems tuo suinteresuotiems subjektams nuo valstybès ir savivaldybės tarnybų, privačių struktūrų iki fizinių asmenų. Pasiūlymų teisè šiuo atveju būtų ne formali, o konstruktyvi ir argumentuota. Šio principo privalumai:

- tai būtų nuolatinis ir platus visuomenès dalyvavimas bendrajame planavime, palyginus su dabartiniu periodiniu oficialiai nustatytu dalyvavimu;

- susikurtų nepaprastai naudinga sistema su grižžtamuoju ryšiu, būtų kaupiama informacija analizei ir atitinkamai reakcijai;

- bent iš dalies būtų identifikuotos tiesioginès mutacijos arba jų inspiruoti investiciniai ir kitokie miesto vystymo siūlymai;

- natūrali prielaida tęstiniam planavimui.

Ketvirta, tęstinis planavimas turi remtis pasiūlymų sisteminės atrankos principu. Sisteminės atrankos funkciją gali atlikti tik patyrę bei kompetentingi profesionalai (pasiūlymų monitoringas, įvertinant siūlomų mutacijų pasekmes ir galimą TPD transformaciją).

Penkta, iškyla klausimas, kaip ir kokia metodika būtų taikoma pasiūlymams ịvertinti. Egzistuoja toks formalus pasirinkimas: nustatytų planavimo procedūru patikrinimas, kokybinis aptarimas ar ekspertizès, kurias galètų atlikti (ir atlieka) ekonomistai, sociologai, architektai bei kiti ekspertai, kiekvienas iš jų turi savo sampratą, metodiką ir priemones. Tačiau toks pasirinkimas dažniausiai yra aklavietè. Straipsnio autoriai ịvertinimo baze siūlo pasirinkti urbanistinę sistemą. Kiekvienas gautas pasiūlymas vertintinas pagal tiesiogines pasekmes, kurios galètu atsirasti konkrečioje miesto sistemoje ar posistemyje ir jo fizineje bei funkcinèje struktūroje. Šio straipsnio turinys leidžia tvirtinti, kad būtina vertinti ir pagal pasekmių rezultatus - galinčias susiformuoti teigiamas ir neigiamas mutacijas.

Taigi bendrąji planavimą reikia pripažinti ne vien lanksčiu, tęstiniu procesu, reaguojančiu ị besikeičiančias sąlygas, galimybes, vienokios ar kitokios naudos supratimą, bet ir stochastiniu procesu. Tuo labiau kad ir dabar niekas neprisiima atsakomybès igyvendinti sprendinius per tam tikrą laiką miesto erdvèje. Todèl bendrasis planas kol kas yra silpnas argumentas apsispręsti gyventi ir veikti dabar bei artimiausioje ateityje.

Tokiame procese net teoriškai nèra prasmès standartizuoti bendrojo planavimo procesą ir bendrąji 
planą - dokumentą, čia įvairovė yra neišvengiama. Svarbiausias elementas yra visuomenès teikiamų pasiūlymų atrinkimo, bendrojo planavimo variantų ir sprendinių i̇vertinimo standartizuota metodika. Tai visos dabartinès nepastovios planavimo sistemos silpniausia vieta. Viena iš išorinių priežasčių - silpnai išvystyta urbanistinių procesų analizè ir studijos, teoriniai darbai, kurie galètų padèti kurti naujų galimybių studijų pasiūlą ir veikti informacinès bazès principu. Kita - nėra suinteresuotų institucijų, kurioms toks procesų valdymas būtų naudingas.

\section{Urbanistinès teorijos ir praktika}

Miestai nèra idealūs, tuo labiau kad idealumo vertinimas priklauso nuo pasirinktų kriterijų. Pastarąji dešimtmetị kaip sėkmingi pavyzdžiai dažniau minimi Kopenhaga, Roterdamas, Lionas ir dar keletas miestu dèl to, kad jie artimesni darniosios plètros koncepcijai.

Per pastaruosius $100 \mathrm{~m}$. pasikeitè daug koncepcijų, svarbiausios yra keturios.

Kiekviena paliko pèdsaką. E. Howardo miestai-sodai išliko patraukli, bet neiggyvendinta idilija. Atènų chartijos propaguotas funkcinis zonavimas arba funkcinè dezintegracija buvo pripažinta kaip 8-9 dešimtmečių miestų krizès esminè priežastis. Funkcinès integracijos koncepcija gyvavo palyginti trumpai ir tik kai kuriuose Europos miestuose maždaug iki 1989 m., kurie laikomi oficialia darniosios plètros koncepcijos gimimo data.

Darnioji plètra kokybiškai naujas produktas, iš ankstesniųjų teorijų, koncepcijų ir praktikos peremęs daug esminių miestų planavimo principų. Kai kas randa darniosios plètros šaknis XIV-XV a. Urbanistinių teorijų ir koncepcijų evoliucija (pagal ṣ̌ straipsnị galima sakyti - mutacija) tęsiasi.

Pirmaisiais po darniosios plètros koncepcijos (DPK) paskelbimo metais ji gyvavo politiniame lygmenyje, kuriame pati idejja buvo suprantama iš esmès vienodai šalių, viena ar kita forma deklaravusių pritarimą daugybei chartijų ir kitokių tarptautinių dokumentų. Tačiau per du dešimtmečius DPK perejo ị kitą - urbanistinio planavimo ir projektavimo - lygmeni. Taip atsirado daugybe interpretacijų. Pragmatinis tipas būdingas Vokietijai, Skandinavijos šalims; Pietų Europos šalyse darnaus miesto įvaizdis siejamas su viešųu erdviu kokybe bei socialiniu patrauklumu gyventi klasikiniame mieste; turtingos ir neturtingos, tankiai ar retai apgyvendintos šalys renkasi specifinius plètros prioritetus. Šiame interpretacijų procese dalyvauja ir JT, ES institutai, ịvairios tarptautinès organizacijos.

Miestų ar šalių tradicijos, istorija, finansinès ir kitos galimybès, urbanistinè politika - tai veiksniai, kurie paskatino darniosios plètros formų atsiradimą (plačiau monografijoje Juškevičius, Valeika 2007):

- laisvas pasirinkimas iš praeityje sukurtų problemų sprendimo būdų. Pavyzdžiui, integruotos urbanistinès struktūros ir viešojo transporto plètra $1934 \mathrm{~m}$. Amsterdame, 1947 m. Kopenhagoje arba $1988 \mathrm{~m}$. Olandijoje gatvių ir viešojo transporto mazgų bei imonių dislokacijos integracija, t. y. pasirenkami žinomi, patikrinti ir efektyvūs problemų sprendimo būdai;

- policentrinè struktūra, pripažịstama kaip kompromisinis sprendimo būdas, kurio efektai - didèja susisiekimo pésčiomis tikimybè, ilgi ryšiai sutrumpèja, sumažinama miesto centro apkrova ir kamščiu tikimybė;

- kompaktinis ir tankiai užstatytas miestas - formaliai ekonomiškai ir socialiai efektyvus principas, nors jis turi daugybę neigiamų pasekmių (gyvenamosios aplinkos ir psichologinis diskomfortas, automobilių statymo problema);

- decentralizuota koncentracija - efektyvus miesto plètros, chaotiškos suburbanizacijos valdymo ir viešojo bejgių transporto integracijos būdas;

- atnaujintas miestas - tai maždaug nuo $1970 \mathrm{~m}$. Olandijoje patikrinta ideja: nuolatinis techninis ir funkcinis miesto struktūrų, sistemų ir erdvių pertvarkymas, kuriam apibūdinti tinka konversijos, revitalizacijos, regeneracijos, rekonstrukcijos, rehabilitacijos, reutilizacijos ir kitos sąvokos. Tai miesto žemès taupymas, alternatyva miestų išskydimui;

- sala (darnusis kompleksas) kaip kontrastas ir DPK (darniosios plètros koncepcija) privalumų vitrina ją supančioje esamoje urbanistinëje aplinkoje. Visų gyvenimo tokioje saloje privalumai pakiša mintit, kad ši darniosios plètros forma ir išliks lokali, nes transformuoti visą urbanistinę sistemą yra utopija. Šiose darniosios pletros formose (3 pav.) nesunku ižvelgti du svarbiausius dalykus. Pirma, urbanistinio planavimo srityje naudojami tiek naujų, tiek senų teorijų ir koncepcijų principai, jeigu galima nustatyti jų efektyvumą, t. y. teigiamas ir neigiamas tiesiogines pasekmes, taip pat ir galimas mutacijas. Antra - ivvairiais būdais viešajam transportui ir susisiekimui pèsčiomis suteikti ne formalų, o realų viešojo transporto patrauklumą. Čia galima ižzvelgti tam tikrą nostalgiją 

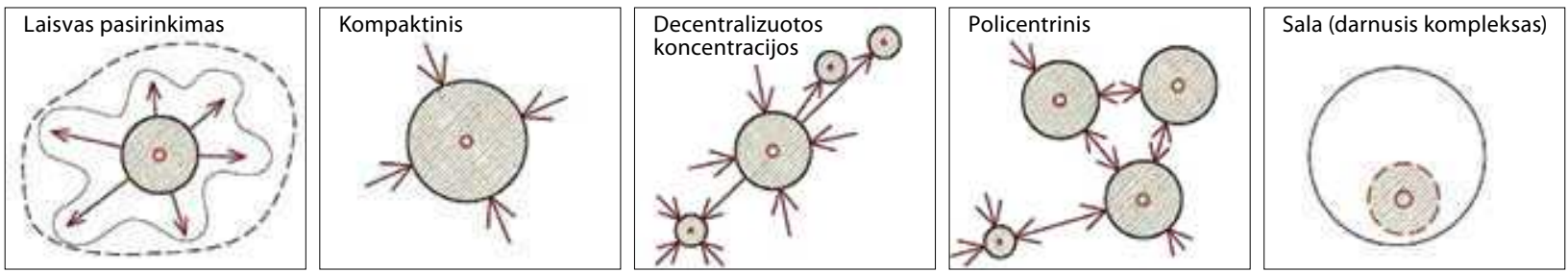

3 pav. Urbanistinè morfologija

Fig. 3. Urban morphology

klasikiniam miestui, kurio viešojo transporto sistemos vystymas buvo esminè miesto valdymo priemonè. Dabar miestai yra seniai ir labai nutolę nuo klasikinio miesto turinio ir fiziniu ribų. Todèl, kita vertus, atkaklus viešojo transporto propagavimas ir pastangos iš dalies panašūs ị savotišką baimę tų pasekmių, kurios atsiranda dèl kol kas (jau apie $40 \mathrm{~m}$.) nesuvaldytos miestų ekspansijos.

DPK (darniosios plètros koncepcija) požiūriu Lietuvos planavimo sistema yra liberali, nes viskas kol kas lieka politinio deklaravimo lygmenyje. Todèl pagal planavimo analogus, kompiliuojant ar kūrybiškai laisvai galima pasirinkti bet kurią darniosios plètros formą, jų kombinacijas ar elementus, kurti savas koncepcijas. Sąlygiškai tai pliusas. Tokios situacijos minusas - nèra planavimų įvertinimo atskaitos taško, t. y. nèra susitarimo dèl generalinio tikslo. Pagal miestų ir miestelių bendrujų planų rengimo taisykles apie toki tikslą neužsimenama, tačiau nurodomos mažiausiai 9 ịvairialypès grupès uždavinių, kuriuos turi išspręsti bendrasis planas.

Jungtinių Tautų „,Habitat“" konferencijoje 1976 m. buvo paskelbta, kad gyvenimo kokybès gerinimas yra vienintelis ir svarbiausias miesto pletros tikslas. Darnioji plètra geriausiu atveju yra tik būdas, principų visuma, padedanti suvokti, veikti ir siekti gyvenimo kokybės gerẻjimo. Todèl dar kartą norisi pabrèžti, kad darniosios plètros formos, morfologiniai tipai ir jų „optimalumo“, „,efektyvumo“ etiketès yra ne tik antraeilis, bet ir iš dalies žalingas dalykas, nes neskatina planavimo pažangos. Planavimo prioritetu laikytinos ne idealios urbanistinès formos, o urbanistinių sprendinių sisteminès visumos paieškos. Tokios visumos, kuri skatintų gyvenimo kokybės augimą, o jos augimo kaina būtų pakeliama našta visuomenei. Dabartinè planavimo sistema neịpareigoja apskaičiuoti miesto vystymo kainos. Taigi bendrasis planas igyja dar daugiau neapibrèžtumo elementų - net apytikriai nežinoma miesto sistemos vystymo tiesioginè kaina, miesto funkcionavimo išorès efektų kainos, tikètinų urbanistinių mutacijų svarba kainų lygmeniui ir realizacijos profiliams.

Pirmasis žingsnis, kuris turèjo būti žengtas jau seniai, tai indikatorių sistemos sukūrimas. Nežiūrint skeptiško požiūrio ị DPK, nèra kitos esminès alternatyvos. Todèl teoriniai darniosios plètros pagrindai turètų koreliuoti su indikatorių sistemos turiniu neviršijant bendrojo planavimo kompetencijos, o pastarosios turinys - su gyvenimo kokybės samprata, ịvertinant tikimybinị planavimo pobūdị, ịgyvendinimo neapibrèžtumą. Minèti veiksniai yra susiję su miesto dydžiu ir jo reikšme visos šalies urbanistinejje sistemoje. Todèl visa urbanistinio planavimo sistema turinio bei reikalavimų požiūriu turètų būti supaprastinta ir diferencijuota daugiausiai $\mathfrak{i}$ tris lygmenis: metropolių de fakto egzistuojančių sistemų; vidutinių miestų; mažų miestų sistemų. Mažiausių miestų ir miestelių planavimas turètų būti pats paprasčiausias. Visa tai, apie ką diskutuojama šiame straipsnyje, taikytina tik 5 metropolių sistemoms. Taip būtų ịvertintas veiklos ir vystymo aktyvumas.

Antrasis žingsnis - monitoringo sistema, kuria turètų būti suinteresuotos savivaldybès ir valstybè, nes tai viena iš prielaidų pagrịstam investicijų planavimui ir kitiems makrouždaviniams spręsti. Jos struktūroje veiktų suinteresuotų asmenų pasiūlymų identifikavimo ir vertinimo posistemis. Tačiau tam reikalingos statistinès ir imitacinio modeliavimo priemonès, miesto e. modeliai, reguliarios urbanistinès studijos. Didžiausia tikimybe, kad monitoringo sistemas pajègūs kurti tik didmiesčiai metropolių sistemoms ir tik čia jos greičiausiai atsipirks.

Kuriant Lietuvos planavimo monitoringo sistemą puikūs pavyzdžiai yra Europos Sąjungos šalių praktikos, kai sistema turi vertinimo sistemos kriterijus, kurie yra viešai skelbiami plačiajai visuomenei (Šiaurès Airijos aplinkos agentūra - Northen Ireland Environmental agency, http://www.greenbuildingfo- 
rum.co.uk/). Monitoringo sistema turi kompetentingas ir atestuotas įmones, kurios yra susitarusios dèl kokybiško gyvenamojo būsto, gyvenamųjų teritorijų vertinimo kriterijų ir standartų. Vertinimo standartai ir kriterijai yra susiję su nekilnojamojo turto kainodara (Breeam aplinkos vertinimo metodai 2009 - Breeam the Environmental assesment method, http://www. breeam.org/). Ši ir panašios monitoringo sistemos kuriamos stengiantis efektyviai vystyti teritoriju planavimą bei gerinti jų planavimo ir būsto kokybę, taip pat palaikyti gyvenamojo būto kainų rinkos pusiausvyrą (Darniosios plètros link 2009- Towards-Sustainability, http://www.towards-sustainability.co.uk/).

\section{Darniosios plètros ir mutacijų santykis}

Statistiškai kol kas nèra pagrindo sakyti, kokia miesto plètros dalis yra mutacijų ir kokia dalis - planuotos plètros produktas. Dar sunkiau apibūdinti santykių tarp darniosios plètros tikslų ir mutacijų visumą kaip savaiminių procesų turinį, kuris gali būti teigiamas ir neigiamas. Yra dvi priežastys. Pirmoji - nemokame ívertinti darnumo lygio, nes neturime vertinimo sistemos, darniosios plètros įrankių ir vertinimo kriterijų. Antroji - Lietuvos urbanistikoje ir terminijoje mutacijos sąvoka neegzistuoja. Todèl natūralu, kad nèra specialių studijų, analitinių darbų.

Vienas santykių aspektas aiškus - „,darnioji plètra“ ar „darnus vystymas“ reikalauja ypatingų vadybinių pastangų ir gebejjimų. Mutacijos - priešingai. Svarbu tik atverti vartus informaciniam srautui. Kiti santykiu aspektai yra problema.

Remiantis (Carmona et al. 2003) pagrindiniais darniosios plètros esmę atspindinčiais tikslais turètų būti kuriamas toks miestas (beje, praktinè patirtis rodo, kad tokio tipo pastangos sunkiai suderinamos su esamų urbanistinių sistemų inercija ir mąstymo inercija):

- kompaktiškas ir didelio užstatymo tankio,

- funkciškai ir socialiai integruotas,

- turintis gyvybingą miesto centrą ir jo sistemą,

- turintis kokybiškas viešųjų erdvių ir želdynų sistemas,

- turintis efektyvų viešąj transportą,

- jame turètų būti kuriamos lokalios darbo vietos,

- turètų būti tausojami gamtiniai ištekliai ir resursai,

- turètų būti gebama reaguoti ir lanksčiai prisitaikyti,

- turètų būti biologiškai stiprinama darni aplinka,
- jis turètų būti savarankiškas, gebantis save išlaikyti,

- turètų būti rūpinamasi identiteto išsaugojimu,

- turètų būti tvarkomos ir perdirbamos atliekos ir t.t.

Kaip nèra bendros ES šalių urbanistinio planavimo sistemos bei bendro darniosios plètros supratimo, taip nèra ir bendros nuomonès apie kiekybinius ar kokybinius kompaktiškumo, efektyvumo ir kitus slenksčius. Pavyzdžiui, kompaktiškumo indeksas yra miesto formos rodiklis, todèl pagal formą miestas gali būti kompaktiškas, o pagal užstatymo nenutrūkstamumo kriterijų - dispersinis.

Todèl svarbesnès yra ilgalaikès tendencijos, kurias teoriškai turètų garantuoti bendrojo plano sprendiniai ir sprendinių igyvendinimo gebejimai.

Makropožiūriu nesunku palyginti teorinius darnaus ir faktinio vystymosi vektorius faktinio miesto ribose, nes administracinio (politinio) miesto analizė būtų nekorektiška. Keli charakteringi tipai:

Pirmasis tipas - miestų teritorine ekspansija, kurios priežastys yra daugialypès (4 pav.). Paprastai tai yra gyvenimo būdo ir gyvenimo sąlygų (aplinkos, būsto tipo) laisvo pasirinkimo kontrasto principu (urbanizuota aplinka - gamtiné aplinka) pasekmè. Ekspansija tapo masiniu reiškiniu tada, kai atsirado prielaidos masinè automobilizacija ir finansinès galimybės naujam būstui įsigyti.

Miesto ekspansija - tai procesas laike ir erdveje. Jos, kaip šiuolaikinès urbanistinès problemos, pradžia laikomi XX a. 6-7 dešimtmečiai. Proceso raidos etapai: urbanizacija, suburbanizacija, ruralurbanizacija (dezurbanizacija) ir miesto atgimimas. Tai klasikinis urbanistinès sistemos mutacijos (slinkties) pavyzdys (5 pav.).

Jeigu toks procesas vyksta, jis sukelia pasekmiu griūti (viena pasekmè gimdo kitą):

- struktūrinius pokyčius: gyventojų svorio centras slenka ị periferiją; socialinè infrastruktūra išlieka centriniame branduolyje (klasikiniame mieste); darbo vietų linijinė slinktis iš centrinès ir vidurinès dalies (vadinamojo modernaus miesto, statyto pagal Atėnų chartijos principus) ị periferiją atsiranda subrendus ekspansijos procesui; visose kitose periferinèse faktinio miesto teritorijose absoliučiai vyrauja gyvenamoji funkcija, tiesiogine ir perkeltine prasme išstumianti žemès ūkị. Vyksta nesisteminis ir nestruktūrizuotas miesto vystymas. Tai dabartine Vilniaus vystymosi charakteristika; 


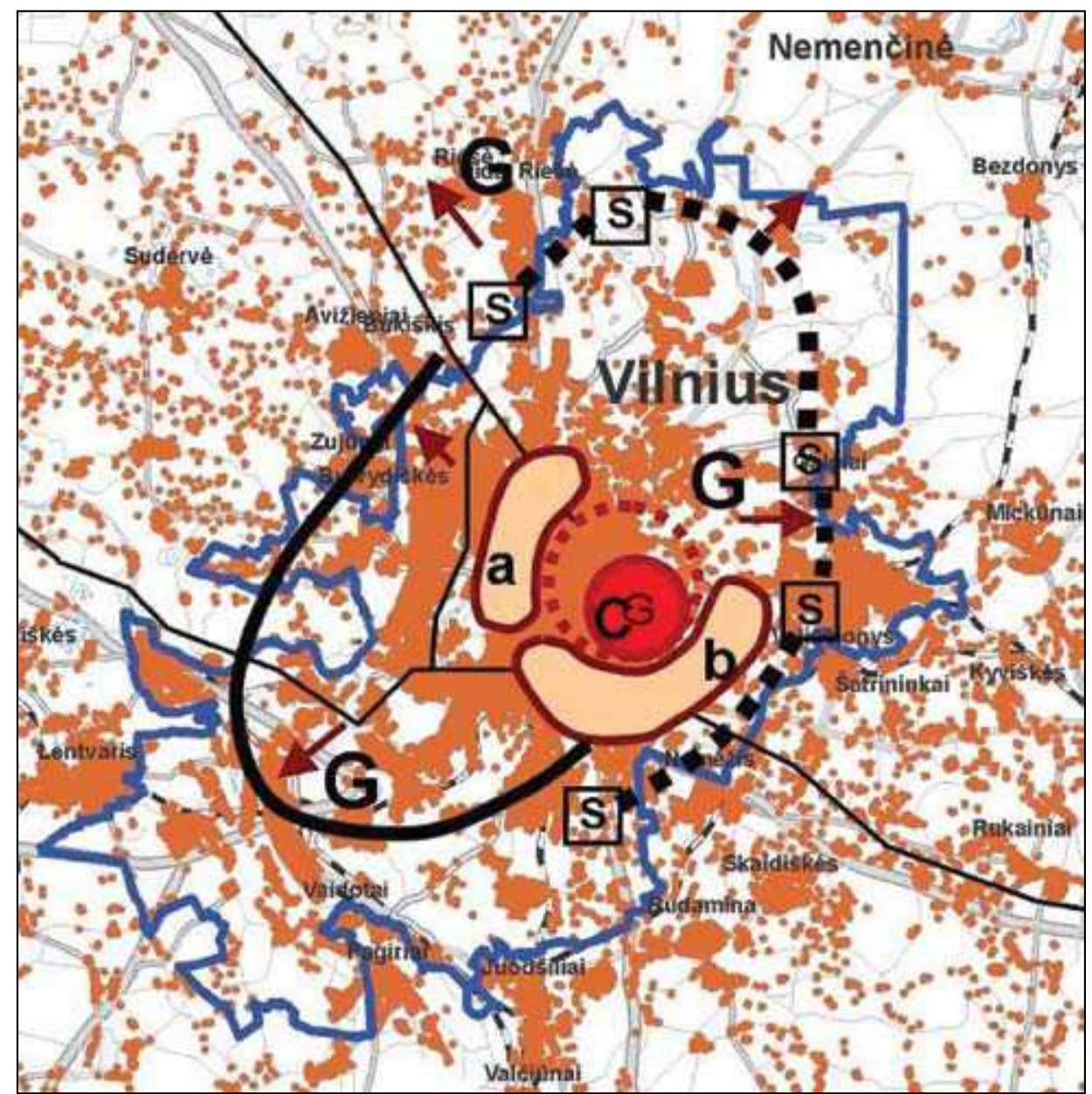

4 pav. Vilniaus miesto teritorinė ekspansija - metropolizacija: C - centro funkcijų sklaida; G - gyventojų slinktis i periferiją, plètros pionieriai - jaunesni ir turtingesni gyventojai; a 1965-1990 m. pagrindinè gyvenamųjų rajonų plètros zona, jos 2005 m. požymiai - didžiausia pensininkų ir mažiausias pajamas gaunančių gyventojụ koncentracija, miesto rūdžių sklaida; b - mažiausio socialinio potencialo erdvé, rudosios teritorijos; s - sodų bendriju mutacija

Fig. 4. Metropolization - Vilnius city territory expansion: $C$ - spread of functions in central area of the city; $\mathrm{G}$ - peripheral residential relocation, development pioneers - young and wealthy residents; a -main residential development area in 1965-1990, territory features in 2005 - largest concentration of retired people and residents with low incomes, area of urban blight spread; $\mathrm{b}$ - space of lowest social potential, brown field territories; $\mathrm{s}$ - mutation of community gardens

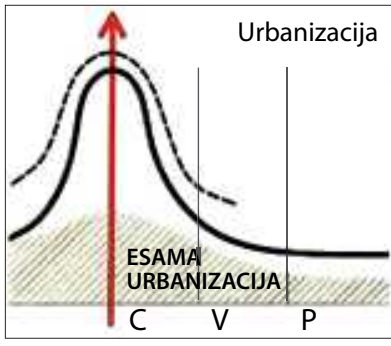

l etapas

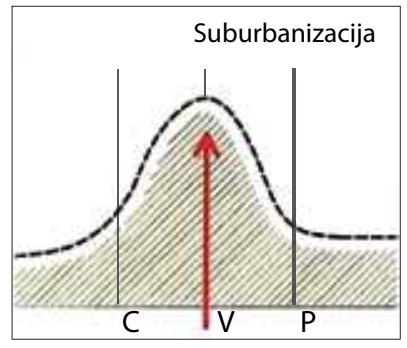

Il etapas

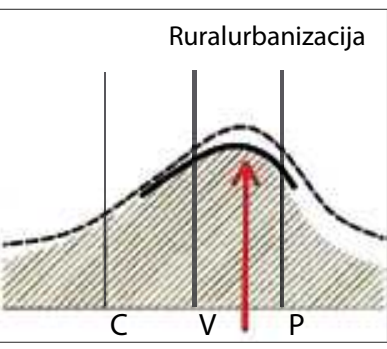

III etapas

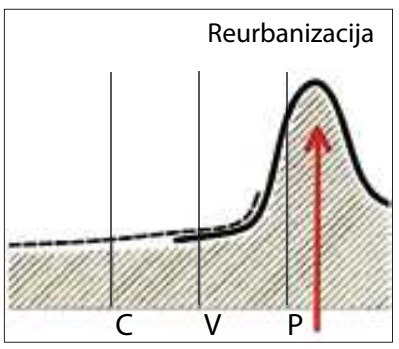

IV etapas

5 pav. Klasikinè miesto urbanistinè ir kokybinè slinktis

Fig. 5. Classical urban and qualitative spread of city 
- funkcinè ir socialinè dezintegracija: darbo ir gyvenamųjų vietų disociacija; pramogų bei paslaugų koncentracija; socialinès diferenciacijos požymiai miesto rajonuose, zonose ir socialinių bei kitokių deviacijų salose. Pavyzdžiui, sporto ir daugiafunkcių centrų koncentracija Vilniaus Ozo gatveje;

- istorinio centro kaita: mažejantis gyventojų skaičius ir besiformuojanti specifinè socialinè, demografinè bei užimtumo struktūra; ryškus gyvybingumo pulsavimas sezonais, savaitgaliais, švenčių dienomis. Pavyzdžiui, Vilniaus senamiesčio, centro gyvenamosios funkcijos nykimas kaip miesto gyvavimo ciklo dalis (6 pav.).

d) viešosios erdvės nesivysto; kokybiškos erdvės išlieka tik centriniame branduolyje; dèl privatizavimo peripetijų daugiabučių namų rajonuose viešosios erdvės mutavo ị niekieno erdves (neprižiūrimas, nei viešas, nei privačias), periferinèje dalyje vien privačios erdvès ir atitinkama bendravimo atmosfera;

e) miesto teritorinė ekspansija apskritai ir struktūriniai pokyčiai konkrečiai, funkcinè ir socialinè dezintegracija, gyventojų tankio mažèjimas - tiesioginiai veiksniai, skatinantys susisiekimą lengvaisiais automobiliais (7 pav.).

Viešojo transporto klestèjimas Lietuvoje baigèsi 1985 m. Nuo šių metų jo reikšmè tolydžiai nusirito (mutavo) ị dabartinị lygmenị, kai vežimų santykis viešuoju ir privačiu transportu yra 3:7. Toks lygmuo paprastai vadinamas socialine paslauga žmonėms, kurie dèl ịvairių priežasčių negali naudotis lengvuoju automobiliu.

Akivaizdu, kad darniosios plètros požymių tendencijos visiškai priešingos realiai susiklosčiusioms čia aprašytoms tendencijoms. Tiesa, tokio pobūdžio metropolizacijos tendencijos būdingiausios šalies didmiesčiams. Mažesniuose miestuose šios tendencijos labai silpnos arba pastebimos tik stagnacinès tendencijos.

Remiantis vien šiuo palyginimu galima konstatuoti, kad urbanistinès mutacijos yra realūs ir galingi procesai, kurių eigai darniosios plètros principų teorinès ir politinès deklaracijos neturi jokios ịtakos. Prieštarą galima sumažinti, tačiau tam reikalingi atitinkami finansiniai šaltiniai, efektyvūs plètros valdymo mechanizmai ir politinè valia. Akivaizdu, kad planavimo sistema turètų keistis. Jeigu bus delsiama, darniosios plètros principų visuma liks tik kaip teorinis, nieko neipareigojantis plètros vektorius.

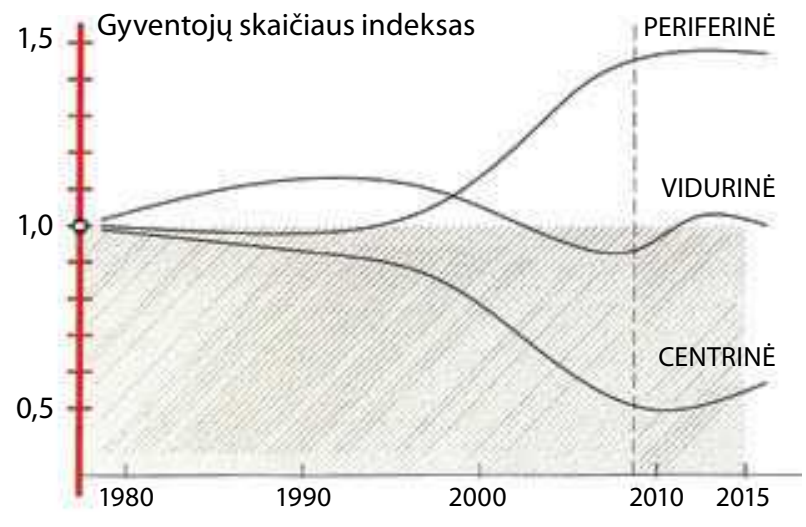

6 pav. Vilniaus miesto gyvavimo ciklu kaitos ir prognozès iliustracija

Fig. 6. Diagram of Vilnius city life cycle changes and forecast

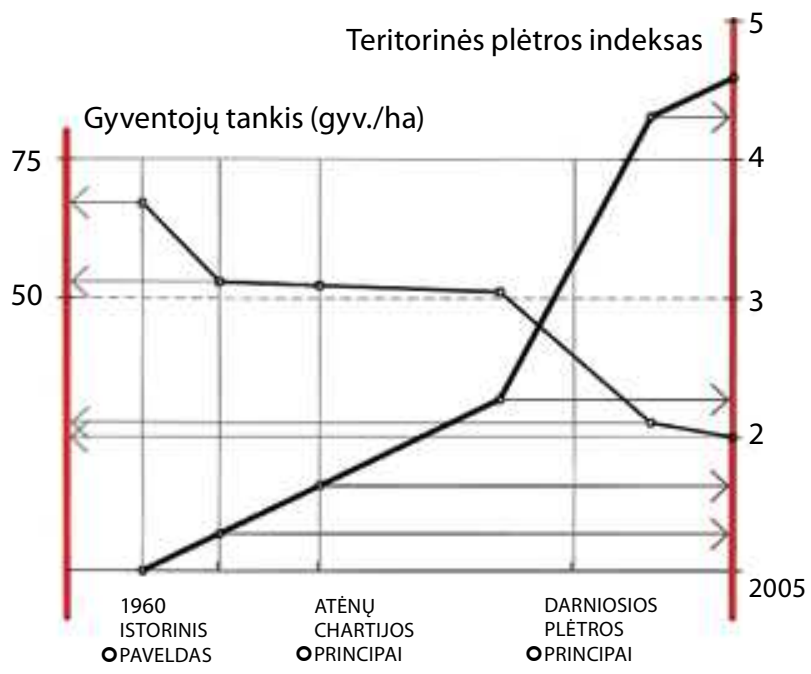

7 pav. Planavimo teorijos ir realios gyventojų tankio bei teritorinès pletros tendencijos

Fig. 7. Trends in planning theory and in real population density and territorial development

Antrasis tipas yra susijęs su miesto komunikacinių ar kitų sistemų vystymo atsilikimu ir pasekmèmis. Vidutinis šalies automobilizacijos lygis nuo 140 l. aut./1000 gyv. 1990 m. padidèjo iki 400500 l. aut./1000 gyv., o kai kur iki dar didesnio lygio. Taigi - išaugo daugiau kaip 3 kartus, o svarbiausių (A, B, C kategorijų) gatvių tinklas, pavyzdžiui, Vilniuje per tą patị laikotarpi - apie 2 proc. Šio straipsnio kontekste svarbios dvi pasekmès. Gatvių tinklo prisotini- 
mas srautu kasmet augo 5-6 proc., todèl ekonominiu, eismo patikimumo ir kokybès požiūriu gatvių tinklas tampa neefektyvus ir nepatikimas, t. y. nevystomas gatvių tinklas savaime nuvertèja. Antroji pasekmè naujai įsisavinamos teritorijos yra nestruktūrizuotos ir neturi jokios užuominos ị reglamentų nustatytus reikalavimus projektuoti hierarchini, rišlų ir struktūrizuotą eismo režimo bei kitais požiūriais gatvių tinklą, išlaikant pagrịstus gatvių erdvių santykius su gretimu apstatymu ir t. t. Realiai svarbiausių gatvių tinklo išvystymas, pavyzdžiui, Vilniuje, atsiliko 20-30 m. Todèl naujos teritorijos įsisavinamos naudojant tik žemiausios D kategorijos gatves ir jungtis su aukštesnių kategorijų gatvèmis bei užmiesčio keliais. Todèl miesto gatvių tinklas mutuoja - kokybiškų savybių tinklas slenka ị primityvaus tipo tinklą, kuris atitinka trumpalaikius finansinius interesus, tačiau ilgam blokuoja strateginių miesto vystymo uždavinių sprendimą, o dažniausiai eliminuoja strateginio vystymo galimybes dèl privačių savininkiškų interesų hipertrofuojant viešumo sąvoką ir teisines interpretacijas (iš kažkur atsiradusi "teisètų lūkesčių“ teisinè praktika). Tai patvirtina R. Rogers (Rogers et al. 2000) tyrimų išvados, kad nepriklausomai nuo žmonių grupès išsivysčiusiose šalyse, kur ekonomikos lygis yra aukštas, mašinas turinčių žmonių skaičius yra mažesnis negu prasčiau ekonomiškai išsivysčiusioje šalyje.

Trečiasis tipas - pastatų ar kompleksų pradinès paskirties mutacijos laike ir erdveje. Bendruoju atveju analizès objektas pagal Galinie (2004) būtų tokie pastatų mutacijos laike 8 tipai (8 pav.).
8 pav. pavaizduoti funkcijų pakitimai yra identifikuoti pagal funkcijų kitimo kriterijus mikro- ir makromasteliu, taip pat pagal nuosavybės charakteristikas, erdvès ilgaamžiškumą ir pirminị identifikavimą. Taip pat šiuos funkcijų kitimus galima būtų sugrupuoti pagal kitimų indikatorius taip (Henry 1999):

- funkcinis pasikeitimas (funkcija, vieta, savybès),

- laikini pasikeitimai (išnykimas ir naujas susikūrimas, stabilumas - išlikimas laikui bėgant),

- vietovès pakeitimas (augimas, „sutrupèjimas“, persiskirstymas, sintezè.

Viena iš aktualiausių mutacijų - vadinamasis urbanistinis rüdijimas. Tai reiškinys, pastebètas $1947 \mathrm{~m}$. Jungtinëje Karalystèje ir 1970 m. Jungtinèse Valstijose. Urbanistinis rūdijimas (arba dar vadinamas miesto amaras) - tai ekonominiai, funkciniai, socialiniai ir fiziniai pasikeitimai, kurie yra tarsi liga, kuri plinta didmiesčių ir bet kurių kitų miestų teritorijose ir gali paversti jas lūšnynais (45 A.L.R. 2007).

Mutacijos susidaro dèl nekokybiško planavimo bei plètros valdymo. Nevaldomas miesto augimas ir chaotiškas namų, pramonès, sandèliavimo, prekybospastatų išdėstymas lemia turto vertės mažèjimą ir „urbanistinị rūdijimą“. Minètų teritorijų pastatai greitai nusidèvi, pasensta dèl didelès gyventojų populiacijos ir intensyvaus naudojimo. Tokie plètros projektai yra tankiai apgyvendinti, o tankis šiose srityse dažnai yra didesnis, nei priimtina pagal „šiuolaikinius planavimo principus"(Hillman, Casey 1950).

Svarbus ir 9 tipas - mutacijų lokalizacinès migracijos požymiai. Jų procesų sklaidos, priežasčių ir inten-

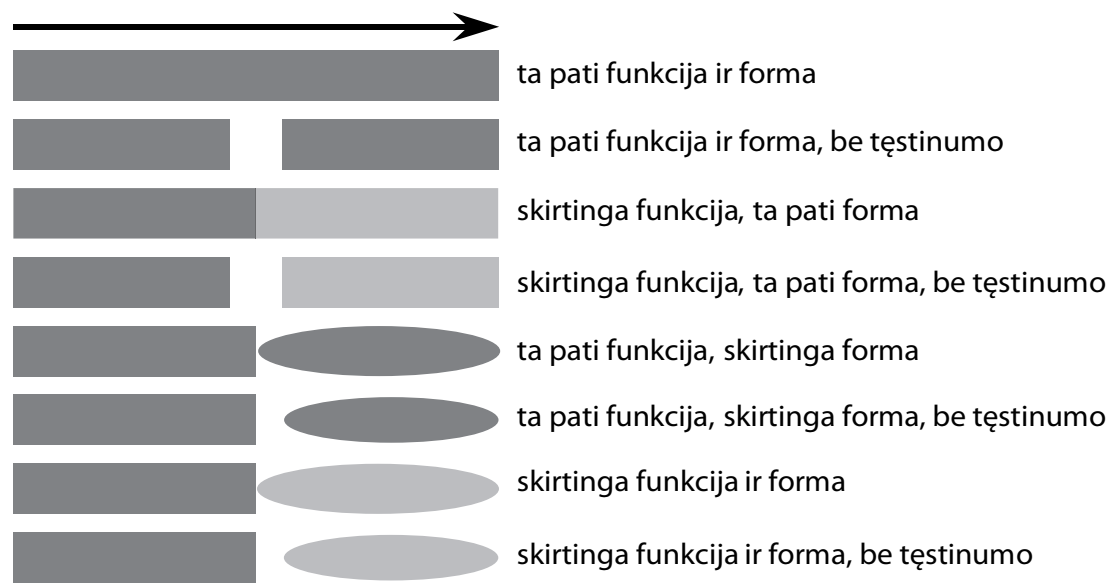

8 pav. Funkcinių mutacijų tipai pastatuose

Fig. 8. Types of functional mutations in buildings 
syvumo identifikavimas laike bei erdveje yra svarbus mažiausiai dviem požiūriais. Pirma, tai argumentai teiginiui, kad dogmatiškas ir tipizuotas funkcinès paskirties, būdų ir pobūdžių supratimas kaip apie nekintamus laike ir erdveje dalykus yra nepagrịstas. Antra, tai bazè miesto vystymo pasekmių prognozei bei atitinkamai miesto plètros valdymo politikai.

Tokių mikromutacijų turinys, sklaida, dažnis ir mastas urbanistiniu požiūriu sistemiškai mažai nagrinèti. Vienas iš kitokių tyrimų rezultatų šia tema yra aprašytas $1995 \mathrm{~m}$. monografijoje (Juškevičius 1995). Esmè: buvo nustatyta, kad Vilniaus gyventoju demografinè struktūra keičiasi tokiu dèsningumu plečiantis miesto teritorijoms jose daugejja jaunesnių gyventojų ir šeimų, kaip pasekmé - seniau statytuose gyvenamuosiuose rajonuose dideja vyresnių gyventoju lyginamasis svoris, o didžiausios disproporcijos susidaro maždaug per $15 \mathrm{~m}$. (9 pav.)

Todèl neatsitiktinai tuose pačiuose rajonuose iš pradžių trūko lopšelių, darželių ir mokyklų, vèliau buvo jų perteklius ir dalis jų buvo uždaryta, kol subrendo sprendimas pakeisti paskirti. Tai galima vadinti gyventojų demografinès struktūros mutacija, kuri jokia for-

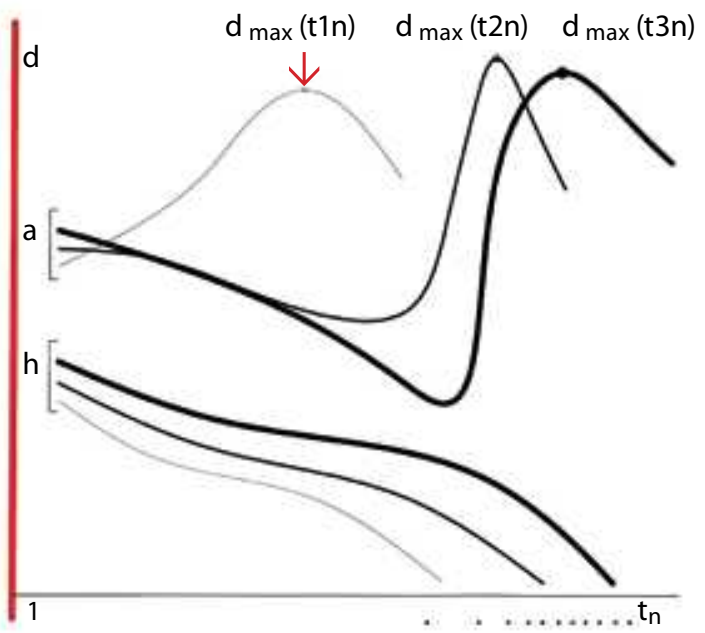

9 pav. Miesto plètra ir gyventoju demografinès struktūros kaita: a - jaunesni gyventojai; $h$ - senesni gyventojai; $\mathrm{d}$ - amžiaus grupių struktūrinè dalis, proc.; $\mathrm{t}_{1}$ - pirminis atskaitos taškas; tn - gyvenamuju rajonu statybos seka erdveje ir laike

Fig. 9. Urban development and change in population demographic structure: $\mathrm{a}$ - younger residents; $\mathrm{h}$ - elder residents; $d$ - structural part of age groups in percentage; $t_{1}$ - primary referente point; $t n$ - development sequence of residential areas in space and time ma nebuvo numatyta ir neịvertinta jokiuose planavimo dokumentuose. Netgi senamiesčiuose laikantis saugojimo režimo gali būti išlaikytos ar net atstatytos pastatų formos, patys pastatai, tačiau negali būti sustabdyta natūrali turinio kaita (kryptinga gyventojų migracija, senų ir naujų funkcijų maišymasis ir mutacijos).

Šis mutacijų tipas apima platų demografinių ir urbanistinių mutacijų (kaip pasekmių) lauką (Rerat 2005). Viena iš jų - šeimų dydžių mažejjimas apskritai ir jų struktūros diferenciacija, miesto erdvèje keičianti viešojo transporto potencialą, socialinès infrastruktūros poreikị ir t. t. Susiformuoja paradoksas - darnioji plètra skatina visais įmanomais būdais didinti gyventojų tankị, realiai tankis be jokių pastangų mažeja. Problema ta, kad tokie procesai vyksta lyg po nežinios skraiste ir geriausiu atveju identifikuojamos tik akivaizdžios, toli pažengusios pasekmès, o pavèluotas bandymas jas sustabdyti ar pradèti reguliuoti dessningai lemia kitas mutacijas.

Ketvirtasis tipas - inicijuotos, specialiai ar netiesiogiai kurstomos mutacijos. Šio tipo esmę atskleidžia dviejų alternatyvų palyginimas. Pirmoji - planavimo bei igyvendinimo etapuose taikomas ,,užbaigto produkto" (nenumato tolimesnio vystymo galimybių) principas. Tokio produkto ryškiausias pavyzdys yra sovietiniais metais suplanuoti ir adekvačiai pastatyti stambūs gyvenamieji rajonai bei jų struktūrinès dalys mikrorajonai. Didžiausios neigiamos savybès: fizinès, funkcinès struktūros monotoniškumas, bendrųjų erdvių absoliutas ir visais požiūriais ilgam užprogramuotas status quo. Todèl esminis jų pertvarkymas dèl pakitusių gyventojų poreikių ar dèl miesto strateginių tikslų kol kas nerealus, greičiau nerasta tinkamų transformacijos būdų. Tačiau taip susiklostè, kad kai kuriuose rajonuose jų centrams rezervuotos teritorijos išliko neužstatytos 20 ir daugiau metų (pvz., Vilniaus Karoliniškių rajone), o per pastaruosius $10-15 \mathrm{~m}$. jas užpildė verslo, paslaugu i̇monès, valstybès ir kitokios ìstaigos, kurių visuma suteikè esminị pokytị - funkcinị integruotumą. Iš čia kyla antroji alternatyva - „,neužbaigto produkto" principas, kuris turètų palikti tam tikrą tiesioginę ir perkeltinę erdvę bei laisvę bent 20 $30 \mathrm{~m}$. (gal ir neribotam laikui) mutacijoms bei transformacijoms. Daugelis dabartinių pastarojo dešimtmečio kompleksų formaliai yra baigtiniai produktai, nors neturi struktūrinių, funkcinès ir socialinès įvairovess požymių ir teritorinių rezervų kokybiniam vystymui.

Antroji alternatyva atitinka bendrąją darniojo ir kitokio planavimo efektyvumo supratimą: svarbiau 
procesas, o ne pats produktas. Todèl bet kurios miestų transformacijos - anksčiau minètos darniosios plètros salos, rekonstrukcijos, konversijos, rehabilitacijos ir pan. - jeigu jos yra tęstinès, sukuria prielaidas bei sąlygas atsirasti ir reguliuoti demografines, socialinio tipo mutacijas, lokalizacinį mobilumą. Esamų urbanistinių vietovių ar kompleksų užbaigtumas dar nèra pagrindinè blogybė. Blogiausia yra tai, kad šis užbaigtumas yra teisetai baigtinis pagal to paties urbanistinio planavimo procesą itteisintas nuosavybès vertes, o jų transformacija yra pati sudètingiausia dabartinèje teisineje aplinkoje.

Straipsnyje neatskleista visa urbanistinių mutacijų ir transformacijų santykių ìvairovè, jų reikšmès bei itakos urbanistinei teorijai bei praktinei planavimo sistemai interpretacijos. Autoriai tikisi, kad iškeltos problemos ir idejjos bus diskutuojamos bei vystomos.

\section{Išvados}

Lietuvoje bendrojo planavimo reikšmè tampa daugiau formali negu reali. Planavimo sistemos trūkumai patys užprogramuoja problemas, sukuria „slenksčius“, kurių iveikti neįmanoma. Vienos iš pagrindinių problemų yra "scenarinis" vystymas nuo pradinio iki galutinio vystymosi lygmens, neatsižvelgiant ị laisvosios rinkos svyravimus, socialinius, ekonominius ir kitus veiksnius, taip atsiradusias nelankstumo pasekmes - mutacijas - tenka perleisti būsimiems BP sprendimams.

Lietuvoje darnioji plètra, gyvavusi politiniame lygmenyje, perèjo ị liberalaus urbanistinio planavimo ir projektavimo lygmeni, kuriame buvo koncepciju interpretacijų galimybè. Koncepcijų efektyvumui ir mutacijoms įvertinti neturime metodų bei įrankių.

Darniosios plètros ir mutacijų santykis yra dvilypis, todèl sunku pasakyti, kokia miesto plettros dalis yra savaiminiai mutacijų procesai ir kokia dalis yra planuotos plètros produktas. Daugelyje miestų makromasteliu darniosios plètros tikslai yra priešingi susiklosčiusioms tendencijoms. Urbanistinès mutacijos yra realūs ir galingi procesai, kuriems darniosios plètros principų teorinès bei politinès deklaracijos neturi jokios įtakos.

Planavimo sistemos lankstumo ir galimybių problematika pastebima aukštojo mokslo sistemoje. Pasaulyje plačiai vartojami probleminių sričių urbanistikos terminai ir sąvokos yra ignoruojamos ir neiteisintos Lietuvoje. Terminologijos, metodų ir sąvokų, tyrimų trūkumas apriboja priemonių, identifikuojančių urbanistinius reiškinius, kūrimą. Dèl to urbanistiniai reiškiniai pastebimi ir ịvardijami praejus keliems dešimtmečiams nuo reiškinių identifikavimo kitose šalyse. Galima teigti, kad neturime priemonių, leidžiančiu profesionaliai identifikuoti problemas urbanistinio planavimo srityje ir siūlyti adekvačius sprendimus, nes esama urbanistikos mokslo sistema apriboja terminologijos ịteisinimą ir metodų kūrimą.

\section{Literatūra}

45 A.L.R. 3rd $1096 \$ 2[a]$ Summary and Comment Background on Urban Redevelopment. 2007. 20 BOSTON U. L. REV.

Berezowska-Azzag, E. La Notion de suils de croissance urbaine comme enju strategique [interaktyvus] [žiūrèta 200907 10]. Prieiga per internetą: <http://www. unil.ch/webdav/site/ouvdd/shared/Colloque\%202005/ Communications/A)\%20Ecologie\%20urbaine/A1/E.\%20 Berezowska-Azzag.pdf $>$.

Bunschoten R.; Goodall, B. 1999. The Dictionary of Human Geography. Fonden Penguin Group.

Carmona, M., et al. 2003. Public places urban spaces: the dimension of urban design. Kent: Archtectural Press.

Darnioji pletra teritoriju planavime ir urbanistikoje. 2008. LNTPA. $110 \mathrm{p}$.

Equipe de recherche urbanisme et amenagement [interaktyvus] [žiūrèta 200907 10]. Prieiga per internetą: <www. iug-grenoble.fr/recherche/presentation.htm $>$.

Galinié, H.; Rodier, X. ; Saligny, L. 2004. Entités fonctionnelles, entités spatiales et dynamique urbaine dans la longue durée [interaktyvus] [žiūrèta 200909 05]. Prieiga per internetą:< http://histoiremesure.revues.org/index761. html>.

Gosse, M. Complexite culturelle et morphologie urbaine [interaktyvus] [žiūrèta 200906 25]. Prieiga per internetą: <www.n-aerus.net/web/sat/workshops/2004/papers/ Goss\%E9.pdf>.

Guadeloupe, P. 2007. Memoire, Mutation et Milieu: Darboussier un site en devenir (Pointe a Pitre Guadeloupe) [interaktyvus] [žiūrèta 200907 10]. Prieiga per internetą: $<$ http://www.maisonarchitecture-971.org/manifestations/doc20062007/20062007-prix1-Notice.pdf>.

Henry, R.; Rodier, X.; Saligny, L. 1999. Entités fonctionnelles. Entity spatiale et dynamique urbaine dans la Longue Durée [interaktyvus] [žiūrèta 200909 08]. Prieiga per internetą: <http://histoiremesure.revues.org/index761.html>.

Hillman, A.; Casey, R. 1950. Tomorrow's Chicago 70. University of Chicago Press.

Ivanow, N. 2003. The metanolis dictionary of advanced architecture. Barcelona. Actar; Hondures.

Juškevičius, P. 1995. Miestų susisiekimo sistemų planavimas. Vilnius: Technika. $212 \mathrm{p}$. 
Juškevičius, P.; Valeika, V. 2007. Lietuvos miestų sistemu raida: monografija. Vilnius: Baltijos kopija. 240 p.

Kalltorp, O., et al. 1997. Cities in transformation - transformation in cities: social and symbolic change of urban space. Brookfield.

Kolipinski, J. 1970. Metody rachunku efektynosci $w$ miejscowym planowaniu przestrzennym $w$ Polsce. Studia, Panstwowe wydawnictwo naukowe tom XXXII, Warszawa. Komitet przestrzennego zagospodarowania kraju Polskiej Akademii Nauk. 128 p.

Koolhaas, R., et al. 2000. Mutations: Howard Project on the City: Stefano Boer, Municipality: Sanford Kwinter; Nadia Tazi, Hans Ulrich Obrist. Barcelona: Actar; Bordeaux.

Les mutations urbaines sous la loupe des sociologues [interaktyvus] [žiūrèta 200907 10]. Prieiga per internetą: <www. unige.ch>.

Mitchell, W. J. 2002. E-topija. Vilnius: Pasviręs pasaulis.

Nielsen, T.; Albertsen, N.; Hemmersam, P. 2004. Mutations: Urban Mutations - periodization, scale and mobility. Kobenhavn.

Rerat, P. Etalement urbain et mutations demographiques ou le paradoxe de la densification et de la deprise d'une villecentre [interaktyvus] [žiūreta 200907 10]. Prieiga per internetą: <http://www.unil.ch/webdav/site/ouvdd/shared/ Colloque\%202005/Communications/A)\%20Ecologie\%20 urbaine/A1/P.\%20Rerat.pdf>.

Rogers, R.; Rogers, R. G.; Power, A. 2000. Cities for a Small Country. London. Faber and Faber.

Simon, P., J.; Seither, F. 2002. Mutations urbaines en cours: quel avenir pour l'urbanite [interaktyvus] [žiūrèta 200907 10]. Prieiga per internetą: <www.cafe-geo.net/article_imp. php3?id_article $=485>$.

Spatial planning and urban development in the ne EU member states. From adjustment to reinvention. 2006. Edited by U. Altrock, S. Guntner, S. Huning, D. Peters. Aldershot. ASHGATE. 292 p.

\section{MUTATIONS AND TRANSFORMATIONS OF URBAN SYSTEMS IN LITHUANIA}

\section{P. Juškevičius, S. Mozūriūnaitė, S. Motieka}

Abstract. The paper discusses several issues related to the formation of new Lithuanian urban practice and theory in the rapidly developing urban environment. Resulting urban mutations and urban implications with problematic areas of contemporary cities are discussed. The authors identify the issues of undetermined and officially unacknowledged aspects and consequences, such as urban mutations, transformations and urban blight, by the inflexible Lithuanian urban planning system. The issue of inertia, lack of ability to adapt to a rapidly changing need of urban, economic fluctuations, and social change of organized development and planning are discussed.

Keywords: mutations, sustainable development, transformations, urban expansion, development management, urban planning.

\section{PRANCIŠKUS JUŠKEVIČIUS}

Dr Habil, Prof, Dept of Urban Design, Vilnius Gediminas Technical University (VGTU), Pylimo g. 26/Traku g. 1, LT- 01132

Vilnius, Lithuania.E-mail:pjuskevicius@gmail.com

Publications: author of over 70 research papers, author or co-author of 5 monographs. Projects: project manager or coauthor of some town master plans, land use project, transport feasibility studies. Research interests: urbanism, urban morphology, public transport, mobility.

\section{SKIRMANTE் MOZŪRIŪNAITE்}

PhD student, assistant, Dept of Urban Design, Vilnius Gediminas Technical University (VGTU), Pylimo g. 26/Traku g. 1, LT- 01132 Vilnius, Lithuania.

E-mail: smozuriunaite@gmail.com

Projects: author or co-author of master plans and detailed plans, individual housing design. Research interests: urbanism, urban functional mutations, urban morphology.

\section{SAULIUS MOTIEKA}

Architect, project manager, Municipal Enterprise, "Vilniaus planas”, Konstitucijos pr. 3, LT-09601 Vilnius, Lithuania. E-mail: saulius.motieka@vplanas.lt;

Assoc Prof, Dept of Urban Design, Vilnius Gediminas Technical University (VGTU), Pylimo g. 26/Traku g. 1, LT- 01132 Vilnius, Lithuania.

Projects: author and project manager of many master plans, detailed plans and building designs. Research interests: urbanism, land use planning. 